\title{
Prediction of financial distress in Tehran Stock Exchange using DEA approach
}

\author{
Mahmoud Mousavi Shiri ${ }^{1}$ and Mahdi Salehi ${ }^{2}$ \\ ${ }^{1}$ Department of Economics and Social Science, Payam-e-Noor University, Pobox 19395-4697, Tehran, Iran \\ ${ }^{2}$ Department of Accounting, Ferdowsi University of Mashhad, Mashhad, Iran, \\ mahdi_salehi54@yahoo.com
}

\begin{abstract}
Data Envelopment Analysis (DEA) is employed as a tool to evaluate the efficiency score of Tehran Stock Exchange. For predicting financial distress, it is designed and tested a model base on efficiency score. Its accuracy was verified by employing another model designed by financial ratios and variables based on Multivariate Discriminant Analysis (MDA). Ultimately, to investigate the effectiveness of firm's efficiency score on financial distress prediction, its score combined with financial ratios is entered in an MDA model. The results show that all the three proposed models, in this paper, have better ability of predicting financial distress in Tehran Stock Exchange for two years prior to its occurrence. It implies that, DEA efficiency score is an effective predictor variable.
\end{abstract}

Keywords: Efficiency score, Data envelopment analysis, Financial distress, Tehran stock exchange.

\section{Introduction}

Due to the effect of corporation's financial distress as well as bankruptcy on different interested groups, the present index of financial distress and bankruptcy warning has been one of the most attractive subjects in different countries. Until now researchers have been using financial ratios in different models based on Multivariate discriminant analysis (MDA) (Altman, 1968; Deakin, 1977; Springate, 1978, Zmijewski, 1984; Altman, 1993; Rujoub et al., 1995; Shirata, 1998; Grice \& Ingram 2001), Logistic and Probit analysis (Ohlson, 1980; Rose \& Giroux, 1984; Zavgren, 1985; Lau, 1987; Aziz et al., 1988; Gilbert et al., 1990; Platt \& Platt, 1990; 1991, Lennox, 1999), Recursive Partitioning Algorithm (RPA) (Frydman et al., 1985; Sung et al., 1999; Mckee \& Greenstein, 2000; Beynon \& Peel, 2001). Of these methods, MDA is the oldest and the most popular in design of bankruptcy models that at the first is employed by Altman (1968). Because of specialties of this method and suitable for test of statistic hypothesis that is related with classification, till now MDA has been interested by researchers for prediction of financial distress and bankruptcy (Christopoulos et al., 2008; Alexakis, 2008), Miller (2009). Models base on MDA presents vision of the firm's financial conditions in general by evaluating different aspects of operations synchronized.

Coordinated by progress in other sciences such as computer and mathematics, financial researchers have attended to use of these sciences in design of financial distress and bankruptcy models. The result of this glance is presented of prediction models base on Rough Sets, Fuzzy logic, Artificial Neural Networks and DEA.

In different research DEA, as one of techniques that calculates efficiency by concentration on input and output variables introduced for prediction of financial distress and bankruptcy (Fernandez \& Smith, 1994; Cielen et al., 2004; Xu \& Wang, 2007; Premachandra et al., 2007).

If a firm has been successful very likely, it will not face bankruptcy and financial distress. One of measures of success is efficiency. In different research DEA were used for calculating the efficiency. The test of efficiency that calculated by DEA in various researches shows that efficiency is correlation with yield of firms and can be a good sign for the firm's success. Lim and Chu (1998) for testing this correlation used information of banks in a DEA model. At first, they calculated efficiency by capital, interest expense and operational expenses as inputs and increase on average of assets and revenue as outputs, and then they calculated the efficiency by the same inputs and net income separately as output. The results show that when net income is applied as output, between stock return and efficiency that was calculated by DEA, is correlated. Other researchers accepted the same result with different variables based on DEA. For example, Nahm and Kirkwood (2003) concluded that by using two model bases on DEA with the same inputs including Non-Interest Income, Physical Capital and Labor, and outputs contain Profit before Tax and Abnormal Items separately. Halkos and Salamouris (2004) concluded that banks with higher assets (as only input) have higher efficiency. Duzakin (2005) concludes the same result by applying book value of assets and number of Staff as inputs and Profit before Tax, Gross value added and Export revenue as outputs. Yang and Chang (2008) by using number of staff, operational expenses and research and development expenses as inputs, sales and cost of production as outputs given result that efficiency calculated by DEA can evaluate success of the firms.

By considering the ability of DEA in the evaluation of a firm, DEA can be used for analyzing financial statements (Halkos 
\& Salamouris, 2004). Some researchers have tried to use this technique in prediction of bankruptcy and financial distress. Fernandez and Smith (1994) believed that applying DEA is useful for predicting the financial distress as a supplementary of financial ratios. Xu and Wang (2007) conclude that to use the variable of efficiency that can be calculated by DEA, combining it with the financial ratios, can improve the prediction of corporation's financial distress. Cielen et al. (2004) compared ability of a bankruptcy model based on DEA and bankruptcy models based on decision tree and liner programming. They applied eleven of financial ratios that were used in prior researches. They used financial ratios with positive correlation as inputs and financial ratios with negative correlation as outputs. They concluded that model based on DEA have better ability for prediction than other models. Premachandra et al. (2007) divided samples for training sample and hold-out sample groups and used nine financial ratios (seven financial ratios as inputs and two financial ratios as outputs) for designing two bankruptcy models based on logistic analysis and DEA. They concluded that for training sample, accuracy of model based on logistic analysis is better than model based on DEA; but the accuracy of model based on DEA for holdout sample is better than model based on logistic analysis.

Lim and Chu (1998) employed DEA on capital inflow (capital), interest expense (interest expense) and operating costs (operational) (expense), with annual output growth in average assets (assets) and banks and other incomes wherein the net profit efficiency measures the output. The results showed the efficiency calculated based on net output (net income) and stock returns of banks.

Nahm and Kirkwood (2003) studied Australian bank efficiency using DEA and its correlation with stock returns. Similar to Lim and Chu (1998) they also used two models with two outputs to measure the performance. Model inputs for Physical Capital, Non-Interest Income, Labor, and outputs the Profit before Tax and Abnormal Items. The results strengthen the hypothesis that the relationship between performance and efficiency is calculated by envelopment analysis.

Halkos and Salamouris (2004) used DEA to evaluate the performance of banking sector in Greece. Results showed that the DEA technique can also replace the complementary methods to analyze financial ratios used. The results indicate that banks have more assets are more efficient.

Duzakin (2005) measures the efficiency, book value of assets and number of employees and gross value added as input and Profit before tax and export revenue considered as outputs. The results indicate the ability of DEA to evaluate the performance of companies.

Sufian et al. (2007) showed that the performance variable is calculated by the DEA criteria for performance evaluation is appropriate. Using data envelopment analysis, the relationship between performance and stock returns of banks in Singapore was compared. It was concluded that the stock returns of efficient banks are more efficient compared to inefficient banks.

Yang and Chang (2008) evaluated the performance of companies in Taiwan. Fernandez and Smith (1994) aimed to investigate the potential of the DEA in financial distress prediction of companies. Their sample included 27 companies and 27 distressed firms of similar size. Their six financial ratios were selected as input. They concluded that the DEA approach is suitable for financial distress perdition.

Cielen et al. (2004) developed a model using data envelopment analysis and the results of two model-based decision tree and linear programming (liner programming) were compared. They concluded that based on DEA model, other models were designed with higher predictability. The results of Xu and Wang (2007) performance scores were calculated by the DEA as a useful variable in predicting financial distress introduced into performance scores, diagnostic models, logit and decision tree models to improve the predictability.

Premachandra et al. (2007) attempted to design a model based on DEA. Their training and test samples of each of them that were examined included distressed companies and companies. They designed their own pattern of seven financial ratios as input and the output used as financial results. They showed that the samples based on DEA model works better.

Sorayaei et al. (2012) studied about the forecasting stock exchange in Iran. The authors employed two Neural Networks estimation procedures, (i.e. FNN and ANN) to forecast the process of the risk of investors in Iranian stock exchange in automobile industries. The outcomes of the study indicate the applicability of the fuzzy neural network approach for investors in stock exchange. Also the FNN is a practical approach for modeling the risk of investing in the stock exchange in automobile industries in Iran, specially with more efficiency and also much more precision in forecasting value of stock exchange.

By considering the above discussion in this research, it is tried to combine the financial ratios with efficiency variables (calculated by DEA) in prediction of financial distress. With this aim, we tested the hypothesis based on MDA.

\subsection{Research hypotheses}

According to the objectives of the study, the following hypotheses are postulated:

$\mathrm{H}_{1}$ : Companies' financial distress can be predicted with a model based on DEA. 
$\mathrm{H}_{2}$ : Companies' financial distress can be predicted with a model-based diagnostic analysis.

$\mathrm{H}_{3}$ : Companies' financial distress can be predicted with a pattern-based diagnostic analysis of predicted performance scores.

$\mathrm{H}_{4}$ : The overall prediction accuracy and precision of the prediction model based on the DEA model is based on the diagnostic analysis.

$\mathrm{H}_{5}$ : The overall prediction accuracy of model-based Diagnostic analysis of performance scores and diagnostic accuracy of the prediction model based analysis is a difference.

DEA

Divided by the total product value outputs (prices or values) corresponding to the total amount of product data in the coefficient of efficiency was calculated as:

(All data were weighted) / (The weighted sum of outputs) = Efficiency

DEA can be used in most cases when coefficients (price or value) and outputs of the data are unknown and when the data have different scales and outputs. DEA nonparametric method (non-parametric) based on linear programming can be used to determine the effectiveness of the decision maker or business units based on the data. In this method, data and output coefficients for each operating unit (Decision Making Unit) are determined in such a way that it will maximize the efficiency of the unit. It can be claimed if the operational efficiency of a single decision unit is further provided with the resources of the unit under study to produce more output (output oriented).

Mathematical models show the relative BCC (Banker, Charnes \& Cooper) is as follows:

$$
\operatorname{Max} Z=\frac{\sum_{r=1}^{S} u_{r} y_{p}+w}{\sum_{i=1}^{m} v_{i} x_{\dot{D}}}
$$

s.t :

$$
\frac{\sum_{r=1}^{S} u_{r} y_{\dot{\boldsymbol{j}}}+w}{\sum_{i=1}^{m} v_{i} x_{\boldsymbol{j}}} \leq 1
$$

$u_{r}, v_{i} \geq 0, w=$ free

$i=(1,2,3, \ldots, m), r=(1,2, \ldots, s), j=(1,2, \ldots, n)$

\subsection{The relative pattern of BCC}

The objective function in this model, the performance review of the decision unit (zero- unit) under the constraints that must be smaller than or equal to a maximum efficiency of all units. This pattern of relative differences in the pattern of CCR (Charnes, Cooper \& Rhoods) are only free variable in the symbol w (variable returns to scale) is. The solution of this model separately for each of the units of a number between zero and obtained the efficiency scores efficiency scores indicate that the unit will be effective or ineffective, it is. This pattern is a pattern Fractional Programming can view it with the performance of Focusing on inputs or outputs to focus on the performance of a linear model into. Focus on the outputs of the output-oriented BCC model (output oriented (and focus on the input to the input-oriented BCC model is. In addition, the BCC model is a linear programming model can also form the main problem and the dual simplex method is the main issue. Model based on the key issue is the design, form and pattern of a multiple core design is based on the dual form is called a cover.

Show BCC input-oriented model to cover the mathematical form is as follows:

$$
\begin{aligned}
& \text { Miny }_{0}=\theta-\sum_{r=1}^{S} \varepsilon \cdot s_{r}^{+}-\sum_{i=1}^{m} \varepsilon \cdot s_{i}^{-} \\
& \text {s.t }: \\
& \sum_{j=1}^{n} \lambda_{j} y_{\dot{r}}-s_{r}^{+}=y_{r 0}
\end{aligned}
$$




$$
\begin{aligned}
& x_{i 0} \theta-\sum_{j=1}^{n} x_{j} \lambda_{j}-s_{i}^{-}=0 \\
& \sum_{j=1}^{n} \lambda_{j}=1 \\
& \lambda_{j}, s_{r}^{+}, s_{i}^{-} \geq 0, \theta=\text { free }, j=(1,2, \ldots, n)
\end{aligned}
$$

\subsection{BCC input-oriented model of a cover form}

Optimization process in this model as a two-stage process takes place: The first step in in reducing the maximum data rate by $\theta^{*}$ and secondly to move towards performance boundaries by using auxiliary variables $\left(s_{i}, s_{r}\right)$. Sam efficient decision making is that if $\theta^{*}=1$ and the covariates are equal to zero Non-zero values of covariates and $\theta^{*}<1$, respectively, and a source of inefficiency in each decision shows.

\section{Research methodology}

The research method used in this research field method using historical data in both healthy and distressed companies subject to Article 141 of Iran's trade in both distressed and healthy companies in the classification criteria are intended.

The society of the study as following features:

1. Select distressed companies: For distressed companies, the companies that manufactured 2000 to 2010 are covered by Article 141 of Iran's trade (Criteria of financial distress in this study) 60 companies were selected using simple random sampling.

2. Choose healthy companies: After the 60 companies desperate for any of these companies, a company was selected as a safe pair. Healthy couples desperate for any company, three conditions were considered. First is produced, Second, the financial information in the corresponding period of the study sample is helpless, third, the size is consistent with the desperate (In the event of financial distress) Criteria and criteria reflecting the size of the company's total assets were considered.

3. The training and test samples: note that using separate training and test samples, one of the best ways to validate a pattern. 60 pairs were selected using simple random sampling and pilot training were divided into two equal groups (Each pair consists of a helpless and a healthy companies listed on Tehran Stock Exchange.

Data collected for the sample firms in years $t, t-1, t-2$ and in the event of financial distress for companies desperate years, respectively, One and two years earlier and for healthy firms, in the event of financial distress, one and two years before the couple is desperate.

\subsection{Design pattern based on DEA}

DEA model based design, a sample of companies as an independent decision to be considered. With a view of the operational factors that companies seek to minimize their output with constant input and assuming constant input factors that companies seek to maximize their output. ) Select a background check to investigate factors such as total assets, total liabilities, working capital and operating costs as input, Sales, profits accumulate (retain earning) and net profit (net income) and operating profit (operational income) as the output of the show. Accordingly, considering the background research and provided an operational perspective, total assets as a whole unit of resource decisions on the balance sheet (balance sheet) as the first input and net operating costs as the resources used during the period selected as the second input.

According to the comments raised in the input-oriented BCC model with two inputs and two outputs for the model predictions in this study selected. From this point onwards, designed to predict the pattern using the selected pattern begins. The first point to the educational performance of firms in years of $t$ Pattern is calculated using the selected companies that rated their performance as 1 measure of profits, companies and efficient companies that score and their performance is less than 1 calculated, efficient firm are not. The calculated performance scores of companies, to determine the point of discontinuity (cutoff point) model, numbers calculated from the distribution charts are examined to the point where the lowest classification error occurs (the discontinuity) is determined.

\subsection{Design model based on multivariate analysis of prognostic}

The only model of financial ratios as independent variables (the international) is used. To determine the diagnostic model variables that more than 35 financial ratios and other ratios to predict financial distress and bankruptcy have been used Variables selected as the primary. Reduction process variables for design pattern detection are using multivariate analysis stepwise method. If at 
any stage in the presence of a linear combination of variables is not necessary, it will remove the variable from the equation. The DEA model, like model-based design is based on training samples with the difference that for the design of the $\mathrm{t}, \mathrm{t}-1, \mathrm{t}-2$ and simultaneously used.

\subsection{Design pattern detection using the performance rating}

The possibility to enter performance scores calculated for firms with DEA model based on a diagnostic analysis as independent variables are considered. The purpose of the 35 financial ratios mentioned in the previous section and academic performance scores of all the companies in each of year's t, t- 1 and t- 2 is calculated. This description can be given as the number of variables studied for this model consists of 35 to 36 design variables and financial performance in a variable rate. Results from this study will show whether the company's performance scores can be compared with other financial ratios as well as other variables can be used before the financial distress or not. Be noted that the pattern depends on the ability to predict performance scores is in financial distress.

\subsection{Test patterns designed}

Test patterns designed to determine the accuracy of their classification, and t-1, t-2 years of training, Testing is done separately, and thus the validity of the models can be designed.

\subsection{Test research hypotheses}

First tests of three hypotheses to determine the predictability of financial distress by three pattern designed through the test at the $5 \%$ significance level and for each of years $\mathrm{t}-1, \mathrm{t}-2$ sample and the training and testing is done separately. To test this hypothesis, the expected accuracy of $50 \%$ is considered to be.

The following formula shows how to calculate the test statistic:

$$
Z=\frac{\mathrm{P}_{1}-\mathrm{P}_{0}}{\sqrt{\frac{\mathrm{P}_{0}\left(1-\mathrm{P}_{0}\right)}{\mathrm{N}}}}
$$

Where: $\mathrm{P}_{1}=$ percent of all companies that are classified correctly by the model

$\mathrm{P}_{0}=$ the percentage of the predetermined (expected)

$\mathrm{N}=$ sample size of pattern

The other hypothesis tests to compare the predictive ability of models designed by the Ratio test at the significance level of $5 \%$ for each year is $\mathrm{t}-1, \mathrm{t}-2$ and the sum of the two years separately for each of the samples and the training is done.

The following formula shows how to calculate the test statistic:

$$
Z=\frac{\mathrm{P}_{1}-\mathrm{P}_{2}}{\sqrt{\frac{\mathrm{P}_{1}\left(1-\mathrm{P}_{1}\right)}{\mathrm{N}_{1}}}+\sqrt{\frac{\mathrm{P}_{2}\left(1-\mathrm{P}_{2}\right)}{\mathrm{N}_{2}}}}
$$

Where: $\mathrm{P}_{1}=$ percentage of firms that are classified correctly by the first pattern

$\mathrm{P}_{2}=$ percentage of firms that are classified correctly by the second pattern

$\mathrm{N}_{1}=$ First sample size pattern

$\mathrm{N}_{2}=$ second sample size pattern

\subsection{Design patterns model based on DEA}

The calculated performance scores of companies, with the following chart of pattern discontinuity point was determined based on DEA is shown in Fig. 1. As can be seen in the above table, performance against the best score of 0.4 points for the separation of healthy and distressed companies that are running the model based the slack-based DEA model is designed in this study. This point as a measure of companies are used to both healthy and distressed. If you score less than 0.4 for a company's performance, the company is desperate, and if higher than 0.4, the company predicts will be safe. Results of the test pattern in each of year's t-1 and t-2 Training and testing samples from these companies in calculating performance scores compared with the point of interruption.

Curtailment of the model (X 0.4) obtained in the following tables. Note in this example, no loss of accuracy in predicting the experimental sample to training samples with the exception of $\mathrm{t}-2,5 \%$ decline that could represent a suitable model can be general- 
ized. Table 1 and 2 shows the Test Pattern-based on DEA for training sample.

Fig.1. The distribution of healthy and distressed companies rated the effectiveness of training samples

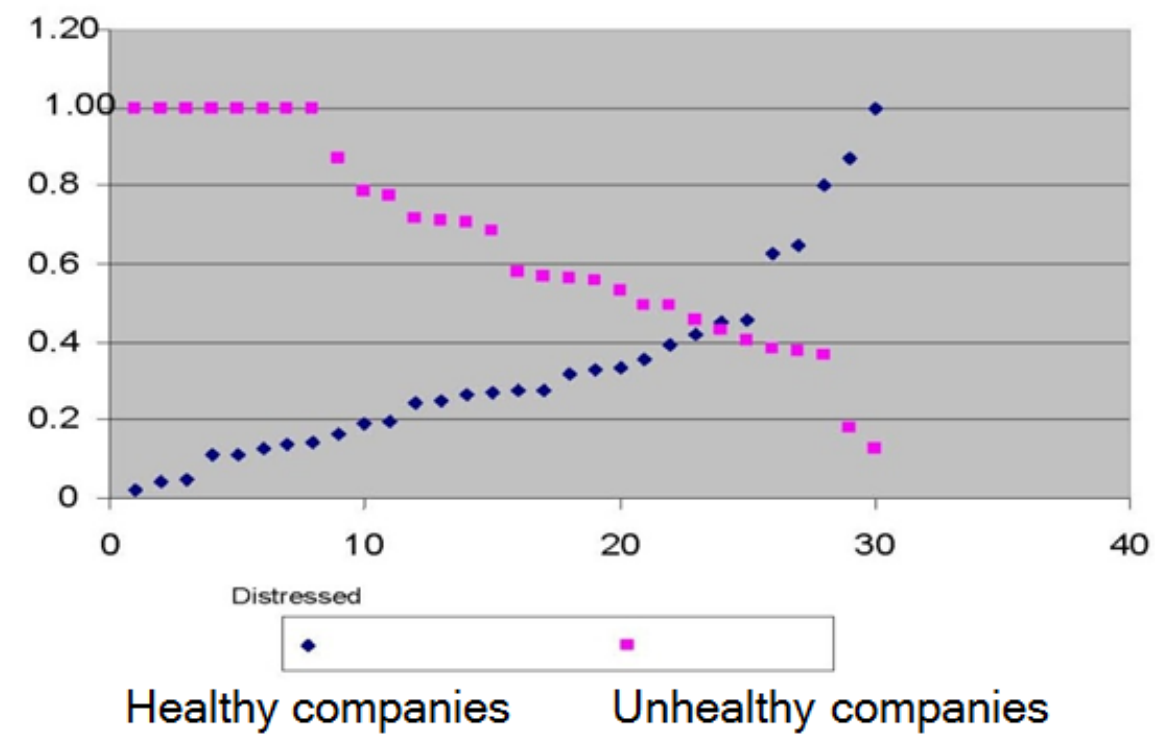

Table 1. Test pattern-based data envelopment analysis (training sample)

\begin{tabular}{|c|c|c|c|c|c|}
\hline Sample & Classification & Year & $\begin{array}{l}\text { correct classifi- } \\
\text { cation }\end{array}$ & $\begin{array}{l}\text { Incorrectly } \\
\text { classified }\end{array}$ & Total \\
\hline \multirow{6}{*}{ • } & General & $1-\mathrm{t}$ & $\begin{array}{c}46 \text { Companies } \\
(76.70 \%)\end{array}$ & $\begin{array}{c}14 \text { Companies } \\
(23.30 \%)\end{array}$ & $\begin{array}{c}60 \text { samples of } \\
100 \%\end{array}$ \\
\hline & & $2-\mathrm{t}$ & $\begin{array}{l}42 \text { Companies } \\
(70.00 \%)\end{array}$ & $\begin{array}{c}18 \text { Companies } \\
(30.00 \%)\end{array}$ & $\begin{array}{c}60 \text { samples of } \\
100 \%\end{array}$ \\
\hline & $\begin{array}{l}\text { Financially dis- } \\
\text { tressed }\end{array}$ & $1-t$ & $\begin{array}{c}19 \text { Companies } \\
(63.30 \%)\end{array}$ & $\begin{array}{l}11 \text { Companies } \\
(36.70 \%)\end{array}$ & $\begin{array}{c}30 \text { samples of } \\
100 \%\end{array}$ \\
\hline & & $2-\mathrm{t}$ & $\begin{array}{l}16 \text { Companies } \\
(53.30 \%)\end{array}$ & $\begin{array}{c}14 \text { Companies } \\
(46.70 \%)\end{array}$ & $\begin{array}{c}30 \text { samples of } \\
100 \%\end{array}$ \\
\hline & Healthy & $1-\mathrm{t}$ & $\begin{array}{l}27 \text { Companies } \\
(90.00 \%)\end{array}$ & $\begin{array}{l}3 \text { Companies } \\
(10.00 \%)\end{array}$ & $\begin{array}{c}30 \text { samples of } \\
100 \%\end{array}$ \\
\hline & & $2-\mathrm{t}$ & $\begin{array}{l}26 \text { Companies } \\
(86.70 \%)\end{array}$ & $\begin{array}{c}4 \text { Companies } \\
(13.30 \%)\end{array}$ & $\begin{array}{c}30 \text { samples of } \\
100 \%\end{array}$ \\
\hline
\end{tabular}

\subsection{Model-based analysis of multiple diagnostic}

The process of reducing variables step-by-step method for the design of this model showed that out of the 35 initial financial ratios, four of the most financially distressed, healthy companies have different capabilities, and therefore, these four variables as the final diagnostic model for the design were determined.

These ratios are:

$\mathrm{X} 5=$ Quick Ratio

$\mathrm{X} 9$ = working capital to total assets (Working Capital/Total Assets)

$\mathrm{X} 14=$ net profit to total assets (Net income/Total Assets)

$\mathrm{X} 24=$ sales margin (gross profit/Sale)

Wilks Luanda test results (5\% significance level) are shown in Table 3 which shows each of these variables has a significant effect in 
both healthy and distressed firms that are classified.

Table 2. Test pattern-based data envelopment analysis (training sample)

\begin{tabular}{|c|c|c|c|c|c|}
\hline Sample & Classification & Year & $\begin{array}{c}\text { correct classifi- } \\
\text { cation }\end{array}$ & $\begin{array}{l}\text { Incorrectly } \\
\text { classified }\end{array}$ & Total \\
\hline \multirow{6}{*}{ 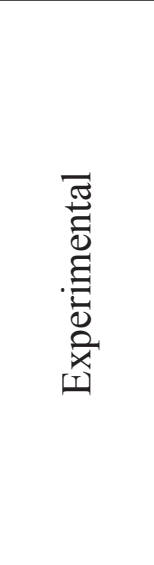 } & General & $1-t$ & $\begin{array}{c}50 \text { Companies } \\
(83.30 \%) \\
\end{array}$ & $\begin{array}{c}10 \text { Companies } \\
(16.70 \%) \\
\end{array}$ & $\begin{array}{c}60 \text { samples of } \\
100 \% \\
\end{array}$ \\
\hline & & $2-t$ & $\begin{array}{c}39 \text { Companies } \\
(65.00 \%) \\
\end{array}$ & $\begin{array}{c}18 \text { Companies } \\
(35.00 \%)\end{array}$ & $\begin{array}{c}60 \text { samples of } \\
100 \% \\
\end{array}$ \\
\hline & $\begin{array}{c}\text { Financially dis- } \\
\text { tressed }\end{array}$ & $1-t$ & $\begin{array}{c}22 \text { Companies } \\
(73.30 \%)\end{array}$ & $\begin{array}{c}11 \text { Companies } \\
(26.70 \%)\end{array}$ & $\begin{array}{c}30 \text { samples of } \\
100 \%\end{array}$ \\
\hline & & $2-t$ & $\begin{array}{c}18 \text { Companies } \\
(60.00 \%)\end{array}$ & $\begin{array}{c}14 \text { Companies } \\
(40.00 \%)\end{array}$ & $\begin{array}{c}30 \text { samples of } \\
100 \% \\
\end{array}$ \\
\hline & Healthy & $1-\mathrm{t}$ & $\begin{array}{c}28 \text { Companies } \\
(93.30 \%)\end{array}$ & $\begin{array}{c}3 \text { Companies } \\
(6.70 \%)\end{array}$ & $\begin{array}{c}30 \text { samples of } \\
100 \% \\
\end{array}$ \\
\hline & & $2-\mathrm{t}$ & $\begin{array}{c}21 \text { Companies } \\
(70.00 \%)\end{array}$ & $\begin{array}{l}4 \text { Companies } \\
(30.00 \%)\end{array}$ & $\begin{array}{c}30 \text { samples of } \\
100 \% \\
\end{array}$ \\
\hline
\end{tabular}

Table 3. Test results Wilks Luanda

\begin{tabular}{|c|c|c|c||c|}
\hline Variable & $\begin{array}{c}\text { Wilks } \\
\text { Luanda }\end{array}$ & F & Sig. & Results \\
\hline \hline X5 & 0.558 & 70.032 & 0.000 & $\begin{array}{c}\text { Significant } \\
\text { effect }\end{array}$ \\
\hline X9 & 0.531 & 38.581 & 0.000 & $\begin{array}{c}\text { Significant } \\
\text { effect }\end{array}$ \\
\hline X14 & 0.579 & 129.187 & 0.000 & $\begin{array}{c}\text { Significant } \\
\text { effect }\end{array}$ \\
\hline X24 & 0.544 & 49.132 & 0.000 & $\begin{array}{c}\text { Significant } \\
\text { effect }\end{array}$ \\
\hline
\end{tabular}

Table 4. Significant results of the test function

\begin{tabular}{|c|c|c|c|c|}
\hline $\begin{array}{c}\text { Function } \\
\text { test }\end{array}$ & D.f & $\begin{array}{c}\text { Chi- } \\
\text { square }\end{array}$ & $\begin{array}{c}\text { Wilks } \\
\text { Luanda }\end{array}$ & Sig. \\
\hline \hline 1 & 4 & 111.278 & 0.531 & 0.000 \\
\hline
\end{tabular}

Table 5. Multivariable analysis of diagnostic test based on the model (training sample)

\begin{tabular}{|c|c|c|c|c|c|}
\hline Total & $\begin{array}{l}\text { Incorrectly } \\
\text { classified }\end{array}$ & $\begin{array}{c}\text { correct } \\
\text { classification }\end{array}$ & Year & Classification & Sample \\
\hline $\begin{array}{c}60 \text { samples of } \\
100 \%\end{array}$ & $\begin{array}{c}7 \text { Companies } \\
(11.70 \%)\end{array}$ & $\begin{array}{c}53 \text { Companies } \\
(88.30 \%)\end{array}$ & $\mathrm{t}-1$ & General & Training \\
\hline $\begin{array}{c}60 \text { samples of } \\
100 \%\end{array}$ & $\begin{array}{c}\text { 11Companies } \\
(18.30 \%)\end{array}$ & $\begin{array}{c}49 \text { Companies } \\
(81.70 \%)\end{array}$ & $t-2$ & & \\
\hline $\begin{array}{c}30 \text { samples of } \\
100 \%\end{array}$ & $\begin{array}{c}5 \text { Companies } \\
(16.70 \%)\end{array}$ & $\begin{array}{c}25 \text { Companies } \\
(83.70 \%)\end{array}$ & $\mathrm{t}-1$ & $\begin{array}{c}\text { Financially dis- } \\
\text { tressed }\end{array}$ & \\
\hline $\begin{array}{c}30 \text { samples of } \\
100 \%\end{array}$ & $\begin{array}{c}8 \text { Companies } \\
(26.70 \%)\end{array}$ & $\begin{array}{c}22 \text { Companies } \\
(73.30 \%)\end{array}$ & $t-2$ & & \\
\hline $\begin{array}{c}30 \text { samples of } \\
100 \%\end{array}$ & $\begin{array}{c}2 \text { Companies } \\
(6.70 \%)\end{array}$ & $\begin{array}{c}28 \text { Companies } \\
(93.30 \%)\end{array}$ & $\mathrm{t}-1$ & Healthy & \\
\hline $\begin{array}{c}30 \text { samples of } \\
100 \%\end{array}$ & $\begin{array}{c}3 \text { Companies } \\
(10.00 \%)\end{array}$ & $\begin{array}{l}27 \text { Companies } \\
(90.00 \%)\end{array}$ & $t-2$ & & \\
\hline
\end{tabular}


Next, using a linear combination of the four diagnostic analysis to determine which way possible to achieve was determined as a linear combination of the possibility of achieving a better (higher accuracy) for separating the two groups of companies out there helpless and healthy The linear combination of the multiple model-based diagnostic analysis in the design in this study have been obtained as follows:

$Z=2.898$ X5 $-1.341 \mathrm{X} 9+7.377 \mathrm{X} 14+2.801 \mathrm{X} 24-1.544$

Function test through Wilks Luanda statistics significant level of $5 \%$ has been done and the results are given in Table 4 confirm the significance of the function.

Table 6. Multivariable analysis of diagnostic test based on the model (Experimental sample)

\begin{tabular}{|c|c|c|c|c|c|}
\hline Total & $\begin{array}{l}\text { Incorrectly } \\
\text { classified }\end{array}$ & $\begin{array}{c}\text { correct } \\
\text { classification }\end{array}$ & Year & Classification & Sample \\
\hline $\begin{array}{c}60 \text { samples of } \\
100 \%\end{array}$ & $\begin{array}{c}9 \text { Companies } \\
(15.00 \%)\end{array}$ & $\begin{array}{c}51 \text { ompanies } \\
(85.00 \%)\end{array}$ & $\mathrm{t}-1$ & \multirow{2}{*}{ General } & \multirow{6}{*}{ 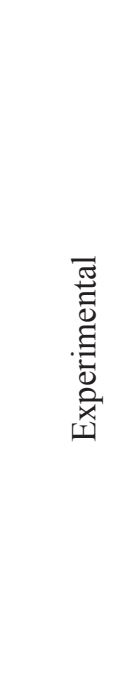 } \\
\hline $\begin{array}{c}60 \text { samples of } \\
100 \%\end{array}$ & $\begin{array}{c}\text { 21Companies } \\
(35.00 \%)\end{array}$ & $\begin{array}{l}39 \text { ompanies } \\
(65.00 \%)\end{array}$ & $\mathrm{t}-2$ & & \\
\hline $\begin{array}{c}30 \text { samples of } \\
100 \%\end{array}$ & $\begin{array}{c}6 \text { Companies } \\
(20.00 \%)\end{array}$ & $\begin{array}{l}24 \text { ompanies } \\
(80.00 \%)\end{array}$ & $\mathrm{t}-1$ & \multirow{2}{*}{$\begin{array}{r}\text { Financially } \\
\text { distressed }\end{array}$} & \\
\hline $\begin{array}{c}30 \text { samples of } \\
100 \%\end{array}$ & $\begin{array}{l}18 \text { ompanies } \\
(60.00 \%)\end{array}$ & $\begin{array}{l}12 \text { ompanies } \\
(40.00 \%)\end{array}$ & $\mathrm{t}-2$ & & \\
\hline $\begin{array}{c}30 \text { samples of } \\
100 \%\end{array}$ & $\begin{array}{l}3 \text { Companies } \\
(10.00 \%)\end{array}$ & $\begin{array}{l}27 \text { ompanies } \\
(90.00 \%)\end{array}$ & $\mathrm{t}-1$ & \multirow{2}{*}{ Healthy } & \\
\hline $\begin{array}{c}30 \text { samples of } \\
100 \%\end{array}$ & $\begin{array}{c}3 \text { Companies } \\
(10.00 \%)\end{array}$ & $\begin{array}{l}27 \text { ompanies } \\
(90.00 \%)\end{array}$ & $\mathrm{t}-2$ & & \\
\hline
\end{tabular}

After the function, calculate and check with the training of company $\mathrm{Z}$ index zero as the point of interruption to this pattern was obtained. The results of the test pattern in each of the t-1 and t-2 the training and test sample is shown in Tables 5 and 6.

Despite the good overall accuracy of this model, a closer examination of the test results accurately predict the sharp drop in distressed companies in the two years prior to the occurrence of financial distress in the prototype shows Model-based diagnostic analysis of performance scores As previously mentioned the possibility of using performance scores on a diagnostic model of the Diagnostic multivariate analysis was performed using stepwise The results of this analysis showed that the rate of financial performance than companies with three quick assets to total assets (Quick Ratio), Working capital to total assets (Working Capital / Total Assets) and Net profit to total assets (Net income / Total Assets) of the 32 financial ratios remain higher ability to predict financial distress are. Significant test results by using these four variables in a linear function of the 5\% significance level in Table 7.

After reducing the variables and confirm the ability to predict performance scores, Model-based analysis using multiple diagnostic performance scores were as follows:

$\mathrm{Z}=2.731 \mathrm{X} 5-1.642 \mathrm{X} 9+8.35 \mathrm{X} 14+1.381 \mathrm{X} 36-1.762$

These ratios are:

X5 = Quick Ratio, X9=Working Capital $/$ Total Assets, X14= Net income/Total Assets, X36= Efficiency score, Ze $=$ the overall index.

Table 7. Test results Wilks Luanda

\begin{tabular}{|c||c||c|c|c|}
\hline \hline Variable & Wilks Luanda & F & Sig. & Results \\
\hline \hline X5 & 0.536 & 50.805 & 0.000 & Significant effect \\
\hline X9 & 0.517 & 408.36 & 0.000 & Significant effect \\
\hline X14 & 0.579 & 129.187 & 0.000 & Significant effect \\
\hline X36 & 0.559 & 71.096 & 0.000 & Significant effect \\
\hline
\end{tabular}


Evaluation of and calculating the Z Index of Business Education, the discontinuity of the pattern was set equal to zero. Results of the test pattern in each of the t-1 and T-2 the training and test samples in Tables of 8 and 9.

Table 8. Multivariable analysis of diagnostic test based on the model (training sample)

\begin{tabular}{|c|c|c|c|c|c|}
\hline Total & $\begin{array}{l}\text { Incorrectly } \\
\text { classified }\end{array}$ & $\begin{array}{c}\text { correct } \\
\text { classification }\end{array}$ & Year & Classification & Sample \\
\hline $\begin{array}{c}60 \text { samples of } \\
100 \%\end{array}$ & $\begin{array}{c}6 \text { Companies } \\
(10.00 \%)\end{array}$ & $\begin{array}{c}6 \text { Companies } \\
(10.00 \%)\end{array}$ & $\mathrm{t}-1$ & \multirow{2}{*}{ General } & \multirow{6}{*}{ 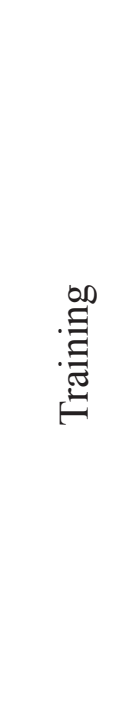 } \\
\hline $\begin{array}{c}30 \text { samples of } \\
100 \%\end{array}$ & $\begin{array}{c}\text { 11Companies } \\
(18.30 \%)\end{array}$ & $\begin{array}{c}\text { 11Companies } \\
(18.30 \%)\end{array}$ & $\mathrm{t}-2$ & & \\
\hline $\begin{array}{c}30 \text { samples of } \\
100 \%\end{array}$ & $\begin{array}{l}3 \text { Companies } \\
(10.00 \%)\end{array}$ & $\begin{array}{l}3 \text { Companies } \\
(10.00 \%)\end{array}$ & $\mathrm{t}-1$ & \multirow{2}{*}{$\begin{array}{l}\text { Financially } \\
\text { distressed }\end{array}$} & \\
\hline $\begin{array}{c}30 \text { samples of } \\
100 \%\end{array}$ & $\begin{array}{c}7 \text { Companies } \\
(23.30 \%)\end{array}$ & $\begin{array}{l}7 \text { Companies } \\
(23.30 \%)\end{array}$ & $\mathrm{t}-2$ & & \\
\hline $\begin{array}{c}30 \text { samples of } \\
100 \%\end{array}$ & $\begin{array}{l}3 \text { Companies } \\
(10.00 \%)\end{array}$ & $\begin{array}{l}3 \text { Companies } \\
(10.00 \%)\end{array}$ & $\mathrm{t}-1$ & \multirow{2}{*}{ Healthy } & \\
\hline $\begin{array}{c}60 \text { samples of } \\
100 \%\end{array}$ & $\begin{array}{c}4 \text { Companies } \\
(13.30 \%)\end{array}$ & $\begin{array}{l}4 \text { Companies } \\
(13.30 \%)\end{array}$ & $\mathrm{t}-2$ & & \\
\hline
\end{tabular}

Table 9. Multivariable analysis of diagnostic test based on the model (Experimental sample)

\begin{tabular}{|c|c|c|c|c|c|}
\hline Total & $\begin{array}{l}\text { Incorrectly } \\
\text { classified }\end{array}$ & $\begin{array}{c}\text { correct } \\
\text { classification }\end{array}$ & Year & Classification & Sample \\
\hline $\begin{array}{c}60 \text { samples of } \\
100 \%\end{array}$ & $\begin{array}{c}10 \text { ompanies } \\
(16.70 \%)\end{array}$ & $\begin{array}{c}50 \text { Companies } \\
(83.30 \%)\end{array}$ & $\mathrm{t}-1$ & \multirow{2}{*}{ General } & \multirow{6}{*}{ 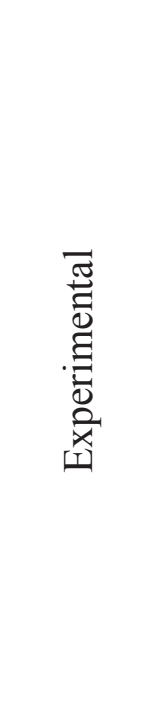 } \\
\hline $\begin{array}{c}60 \text { samples of } \\
100 \%\end{array}$ & $\begin{array}{l}18 \text { ompanies } \\
(30.00 \%)\end{array}$ & $\begin{array}{l}42 \text { Companies } \\
(70.00 \%)\end{array}$ & $\mathrm{t}-2$ & & \\
\hline $\begin{array}{c}30 \text { samples of } \\
100 \%\end{array}$ & $\begin{array}{c}5 \text { Companies } \\
(16.70 \%)\end{array}$ & $\begin{array}{l}25 \text { Companies } \\
(83.30 \%)\end{array}$ & $\mathrm{t}-1$ & \multirow{2}{*}{$\begin{array}{r}\text { Financially } \\
\text { distressed }\end{array}$} & \\
\hline $\begin{array}{c}30 \text { samples of } \\
100 \%\end{array}$ & $\begin{array}{c}13 \text { ompanies } \\
(43.30 \%)\end{array}$ & $\begin{array}{l}17 \text { Companies } \\
(56.70 \%)\end{array}$ & $\mathrm{t}-2$ & & \\
\hline $\begin{array}{c}30 \text { samples of } \\
100 \%\end{array}$ & $\begin{array}{c}5 \text { Companies } \\
(16.70 \%)\end{array}$ & $\begin{array}{c}25 \text { Companies } \\
(83.30 \%)\end{array}$ & $\mathrm{t}-1$ & \multirow{2}{*}{ Healthy } & \\
\hline $\begin{array}{c}30 \text { samples of } \\
100 \%\end{array}$ & $\begin{array}{c}5 \text { Companies } \\
(16.70 \%)\end{array}$ & $\begin{array}{c}25 \text { Companies } \\
(83.30 \%)\end{array}$ & $\mathrm{t}-2$ & & \\
\hline
\end{tabular}

\section{Research findings}

\subsection{The ability to predict patterns}

After the carefully designed patterns, to verify significant results (ability to distinguish healthy and distressed companies by models) to test the significance level of $5 \%$ was used. Results based on a predetermined percentage of accuracy obtained is equal to 50 percent in the Table 10 and 11 are presented.

According to Table 11, $\mathrm{H}_{0}$ is rejected, we can say that the financial distress prediction models developed in this research, 
manufacturing companies listed in Tehran Stock Exchange up to two years before it occurred at a level higher than $50 \%$ correctly done and the first three hypotheses are confirmed.

Table 10. Results of the test coverage analysis capabilities to predict the pattern

\begin{tabular}{|c|c|c|c|c|c|c|c|}
\hline Sample & $\begin{array}{l}\text { Classifica- } \\
\text { tion }\end{array}$ & Z- Value & $\begin{array}{c}\text { Percentage } \\
\text { of Predict } \\
\text { the } \\
\text { expected }\end{array}$ & $\begin{array}{l}\text { Percentage } \\
\text { of correct } \\
\text { predictions }\end{array}$ & Year & P-Value & Results \\
\hline \multirow[t]{2}{*}{ Training } & \multirow[t]{2}{*}{ General } & 4.131 & $50 \%$ & $76.70 \%$ & $\mathrm{t}-1$ & 0.000 & $\mathrm{H} 0$ is rejected \\
\hline & & 3.098 & $50 \%$ & $70.00 \%$ & $\mathrm{t}-2$ & 0.001 & $\mathrm{H} 0$ is rejected \\
\hline \multirow[t]{2}{*}{ Experimental } & \multirow[t]{2}{*}{ General } & 5.164 & $50 \%$ & $83.30 \%$ & $\mathrm{t}-1$ & 0.000 & $\mathrm{H} 0$ is rejected \\
\hline & & 2.323 & $50 \%$ & $65.00 \%$ & $t-2$ & 0.010 & $\mathrm{H} 0$ is rejected \\
\hline
\end{tabular}

Table 11. Results of the analysis of diagnostic test capable of predicting the pattern of performance scores

\begin{tabular}{|c|c|c|c|c|c|c|c|}
\hline Sample & $\begin{array}{l}\text { Classifica- } \\
\text { tion }\end{array}$ & Z-Value & \begin{tabular}{|c|}
$\begin{array}{c}\text { Percentage } \\
\text { of Predict } \\
\text { the } \\
\text { expected }\end{array}$ \\
\end{tabular} & $\begin{array}{l}\text { Percentage } \\
\text { of correct } \\
\text { predictions }\end{array}$ & Year & P-Value & Results \\
\hline \multirow[t]{2}{*}{ Training } & \multirow[t]{2}{*}{ General } & 4.131 & $50 \%$ & $76.70 \%$ & $t-1$ & 0.000 & $\mathrm{H} 0$ is rejected \\
\hline & & 3.098 & $50 \%$ & $70.00 \%$ & $t-2$ & 0.000 & $\mathrm{H} 0$ is rejected \\
\hline \multirow[t]{2}{*}{ Experimental } & \multirow[t]{2}{*}{ General } & 5.164 & $50 \%$ & $83.30 \%$ & $\mathrm{t}-1$ & 0.000 & $\mathrm{H} 0$ is rejected \\
\hline & & 2.323 & $50 \%$ & $65.00 \%$ & $\mathrm{t}-2$ & 0.001 & $\mathrm{H} 0$ is rejected \\
\hline
\end{tabular}

\subsection{Comparing the patterns}

Comparing the patterns of test ratios and a significant level of 5\% each year $t-1$ and $t-2$ and a total of two years of training and test samples were separately.

\subsubsection{Carefully comparing the coverage pattern and diagnostic pattern}

Results of statistical comparison of these two patterns are shown in Table 12 and in those cases where there is significant difference between the two models are demonstrated.

Survey results show that training in the overall performance of the diagnostic pattern in each of the $t-1$ and $t-2$ analysis covering the overall performance of the model is not significantly different. But in two years to review the diagnostic model has better performance than the differences caused disputes arising from accumulating in distressed companies anticipated each year $t-1$ and t-2 in the calculation of two years. Nevertheless, in the prototype, significant differences between the two model years, t-1, t-2 and a total of two years were there. Considering that, a significant difference in the training of the experimental has not been repeated, diagnostic pattern of performance on training samples, possibly using data from three years of training in the design while the design model analysis of the data cover only in the event of financial distress (year $t$ ) is used. It should be noted that there is no significant difference between the results does not mean that they are identical The overall accuracy of the model shows the overall accuracy of predicting the pattern of diagnostic accuracy analysis covering the overall pattern is somewhat more than the general pattern of diagnostic accuracy, while the training sample to experiment sample in the period studied is associated with loss, while the general pattern analysis to cover the training examples with a experiment examples $t$ with less volatility. This could be one of the benefits of the coverage pattern.

\subsubsection{Comparison of the diagnostic model using a model of performance scores and Diagnostics}

Calculations and the results of this test are given in Table 13 show that significant differences between these two models do not general accurately predict. The diagnostic model that accurately predicted by most companies is healthy. 
Table 12. Comparing the test results accurately predict the coverage pattern (pattern 2) and the diagnostic model (model 1)

\begin{tabular}{|c|c|c|c|c|c|c|c|}
\hline Results & P Value & Z Value & Z Value & $\begin{array}{c}\text { Accurately } \\
\text { model } 1\end{array}$ & Year & $\begin{array}{l}\text { Classifi- } \\
\text { cation }\end{array}$ & Sample \\
\hline- & 0.089 & 1.702 & 1.702 & $88.3 \%$ & $\mathrm{t}-1$ & \multirow{3}{*}{ General } & \multirow{9}{*}{ 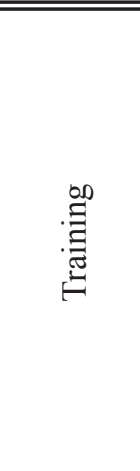 } \\
\hline- & 0.132 & 1.507 & 1.507 & $81.7 \%$ & $\mathrm{t}-2$ & & \\
\hline Significant & 0.025 & 2.249 & 2.249 & $85 \%$ & Sum & & \\
\hline- & 0.072 & 1.798 & 1.798 & $83.3 \%$ & $\mathrm{t}-1$ & \multirow{3}{*}{$\begin{array}{c}\text { Financially } \\
\text { distressed }\end{array}$} & \\
\hline- & 0.100 & 1.643 & 1.643 & $73.3 \%$ & $\mathrm{t}-2$ & & \\
\hline Significant & 0.016 & 3.411 & 3.411 & $78.3 \%$ & Sum & & \\
\hline- & 0.640 & 0.468 & 0.468 & $93.3 \%$ & $\mathrm{t}-1$ & \multirow{3}{*}{ Healthy } & \\
\hline- & 0.687 & 0.403 & 0.403 & $90 \%$ & $t-2$ & & \\
\hline- & 0.542 & 0.610 & 0.610 & $91.6 \%$ & Sum & & \\
\hline- & 0.802 & 0.250 & 0.250 & $85 \%$ & $\mathrm{t}-1$ & \multirow{3}{*}{ General } & \multirow{9}{*}{ 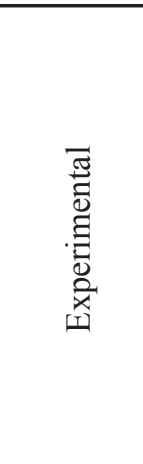 } \\
\hline- & 1.000 & - & - & $65 \%$ & $\mathrm{t}-2$ & & \\
\hline- & 0.882 & 0.148 & 0.148 & $75 \%$ & Sum & & \\
\hline- & 0.540 & 0.612 & 0.612 & $80 \%$ & $\mathrm{t}-1$ & \multirow{3}{*}{$\begin{array}{l}\text { Financially } \\
\text { distressed }\end{array}$} & \\
\hline- & 0.114 & -1.581 & -1.581 & $40 \%$ & $t-2$ & & \\
\hline- & 0.448 & -0.760 & -0.760 & $60 \%$ & Sum & & \\
\hline- & 0.640 & -0.468 & -0.468 & $90 \%$ & $\mathrm{t}-1$ & \multirow{3}{*}{ Healthy } & \\
\hline Significant & 0.046 & 2.000 & 2.000 & $90 \%$ & $\mathrm{t}-2$ & & \\
\hline- & 0.187 & 1.318 & 1.318 & $90 \%$ & Sum & & \\
\hline
\end{tabular}

Table 13. Comparison of diagnostic test results accurately predict the pattern of performance scores (Model 2) and the diagnostic model (model 1)

\begin{tabular}{|c|c|c|c|c|c|c|c|}
\hline Results & P Value & Z Value & Z Value & $\begin{array}{c}\text { Accurately } \\
\text { model } 1 \\
\end{array}$ & Year & $\begin{array}{c}\text { Classifi- } \\
\text { cation } \\
\end{array}$ & Sample \\
\hline- & 0.769 & -0.294 & $90 \%$ & $88.3 \%$ & $\mathrm{t}-1$ & \multirow{3}{*}{ General } & \multirow{9}{*}{ 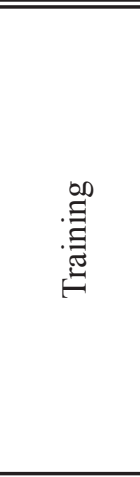 } \\
\hline- & 1.000 & 0.000 & $81.7 \%$ & $81.7 \%$ & $\mathrm{t}-2$ & & \\
\hline- & 0.855 & -0.183 & $85.8 \%$ & $85 \%$ & Sum & & \\
\hline- & 0.445 & -0.763 & $90 \%$ & $88.3 \%$ & $\mathrm{t}-1$ & \multirow{3}{*}{$\begin{array}{l}\text { Financially } \\
\text { distressed }\end{array}$} & \\
\hline- & 0.765 & -0.298 & $76.7 \%$ & $73.3 \%$ & $\mathrm{t}-2$ & & \\
\hline- & 0.486 & -0.697 & $88.3 \%$ & $78.3 \%$ & Sum & & \\
\hline- & 0.640 & $0.468-$ & $90 \%$ & $93.3 \%$ & $\mathrm{t}-1$ & \multirow{3}{*}{ Healthy } & \\
\hline- & 0.687 & 0.403 & $86.7 \%$ & $90 \%$ & $\mathrm{t}-2$ & & \\
\hline- & 0.542 & 0.610 & $88.3 \%$ & $91.6 \%$ & Sum & & \\
\hline- & 0.802 & 0.250 & $88.3 \%$ & $85 \%$ & $\mathrm{t}-1$ & \multirow{3}{*}{ General } & \multirow{9}{*}{ 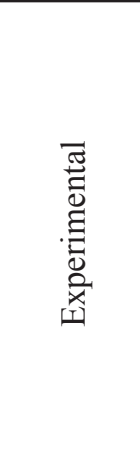 } \\
\hline- & 0.558 & -0.586 & $70 \%$ & $65 \%$ & $\mathrm{t}-2$ & & \\
\hline- & 0.763 & -0.302 & $76.7 \%$ & $75 \%$ & Sum & & \\
\hline- & 0.738 & -0.334 & $88.3 \%$ & $80 \%$ & $\mathrm{t}-1$ & \multirow{3}{*}{$\begin{array}{l}\text { Financially } \\
\text { distressed }\end{array}$} & \\
\hline- & 0.190 & -1.310 & $56.7 \%$ & $40 \%$ & $t-2$ & & \\
\hline- & 0.248 & -1.155 & $70 \%$ & $60 \%$ & Sum & & \\
\hline- & 0.445 & 0.763 & $88.3 \%$ & $90 \%$ & $\mathrm{t}-1$ & \multirow{3}{*}{ Healthy } & \\
\hline- & 0.445 & 0.763 & $88.3 \%$ & $90 \%$ & $t-2$ & & \\
\hline- & 0.280 & 1.079 & $88.3 \%$ & $90 \%$ & Sum & & \\
\hline
\end{tabular}




\section{Conclusion and remarks}

Despite the results of studies on predicting financial distress and companies, that bankruptcy can be a set of financial ratios to predict financial situation and continuing with the help of this company used to predict future events in the payment. But recently the use of predictive variables except financial ratios have also noticed that among the companies that can be used with the DEA efficiency score is calculated so as to calculate the variable before it can be introduced using this method of the raw data for accounting, financial ratios, or even non-financial factors, and also can be used. In this study, the performance of companies using DEA as one of the techniques of operations research has been calculated, as a variable to predict the occurrence of financial distress has been considered. To this end, the first model was designed using DEA. Results of the test pattern on the training and experimental selected samples showed that this pattern could occur up to two years before the occurrence of financial distress in the manufacturing companies to forecast. For better reviews, a model based on multiple diagnostic analyses was designed as a comparative model. Although these models accurately predict the results of the comparison shows that the diagnostic model to analyze the pattern of coverage is somewhat better but envelopment analysis model accurately predicts the motion of the training sample to experimental sample remains almost constant while the diagnostic accuracy of model predictions with multiple instances of the training prototype is associated with loss.

In addition, the model has been introduced in this study for the usability of the performance score as an independent variable along with other financial ratios to predict the financial distress was evaluated using a diagnostic analysis

This study showed that this variable has potential in predicting financial distress and the four-variable model using diagnostic analysis and performance scores as the independent variable was formed to apply. Evaluating the results of the test pattern on the training and experimental examples show that this pattern can be placed in the manufacturing prior to two years of the occurrence of financial distress that can be expected. In the last stage of the research on improving the overall performance of the variable rate Model-based diagnostic analysis of forecast accuracy by comparing the pattern of diagnostic and prognostic model using performance scores. General accuracy of the results of comparing the two models to improve forecast accuracy does not show a significant but an important point in comparing the two models is that the arrival rate performance as a variable to the model, financially distressed companies has increased the forecast of accuracy. Given the importance of correctly predicted distressed companies, companies desperate to predict performance scores improved with variable diagnostic model that can be identified in this study. This variable as a new variable for use in models to predict financial distress using other techniques that are designed (such as models based on logit analysis, probit analysis, neural networks, etc.) to introduce.

\section{References}

1• Alexakis panayotis (2008) Altman z. Score model and prediction of business failures. Int. J. Monetary Econ. \& Finanq. 1(4), $10-23$.

2- Altman E (1968) Financial ratios discriminate analysis and the prediction of corporate bankruptcy. J. Finance, 23(4), 589-609.

3• Altman E (1983) Why businesses fail. J. Bus. Strategy. 3(4), 15-20.

4- Altman E (1993) Corporate financial distress and bankruptcy: $A$ complete guide to predicting \& avoiding distress and profiting from bankruptcy, corporate bankruptcy (2nd Ed.). NY, Wiley. pp: 159.

5• Altman E, Haldeman R and Narayanan P (1977) Zeta analysis: A new model to identify bankruptcy risk of corporations. J. Bank. \& Finan. 1(1), 29-51.

6• Aziz A and Lawson G (1989) Cash flow reporting and financial distress models: Testing of hypotheses. Finan. Manage. 18(1), 55-63.

7• Aziz A, Emanuel D and Lawson G (1988) Bankruptcy prediction - An investigation of cash flow based models. J. Managnt. Stud. 25(5), 419-437.

8- Beynon MJ and Peel MJ (2001) Variable precision rough set theory and data dicretisation: An application to corporate failure prediction. OMEGA Int. J. Manage. Sci. 29, 561-576.

9• Cielen A, Peeters L and Vanhoof K (2004) Bankruptcy prediction using data envelopment analysis. Eur. J. Operational Res. 154, 526-532.

10• Deakin E (1977) Business failure prediction: An empirical analysis. Article in financial crises: Institutions and markets in a fragile environment, E. Altman and A. Sarmetz (Eds.). NY, Wiley-Intersci. pp: 72-98. 
11 Fernandez-Castro A and Smith P (1994) Towards a general nonparametric model of corporate performance. OMEGA Intl. J. Manage. Sci. 22(3), 237-249.

12. Frydman H, Altman E and Kao D (1985) Introducing recursive partitioning for financial classification: The case of financial distress. J. Finan. 40(1), 269-291.

13. Gilbert L, Menon K and Schwartz K (1990) Predicting bankruptcy for firms in financial distress. J. Bus. Finan. \& Accoun. 17(1), 161-171.

14- Grice JS and Ingram RW (2001) Tests of the generalizability of Altman's bankruptcy prediction model. J. Bus. Res. 54, 53-61.

15• Lau A (1987) A five-state financial distress prediction model. J. Accoun. Res. 25(1), 127-138.

16 Lennox C (1999) The accuracy and incremental information content of audit reports in predicting bankruptcy. J. Business Finan. \& Accoun. 26(5/6), 757-778.

17 - Lim Guan Hua and Sing Flat Chu (1998) Share market performance and profit efficiency of banks in an oligopolistic market: Evidence from Singapore. J. Multinational Finan. Manage. 8, 155-168.

18 McKee TE and Greenstein M (2000) Predicting bankruptcy using recursive partitioning and a realistically proportioned data set. J. Finan. 19, 219-230.

19- Miller Warren (2009) Comparing models of corporate bankruptcy prediction: Distance to default vs. score. Available at: $p a$ pers.ssrn.com/sol3/Delivery.cfm?abstractid $=1461704$

20 Ohlson J (1980) Financial ratios and the probabilistic prediction of bankruptcy. J. Accoun. Res. 18(1), 109-131.

21 Platt HD and Platt MB (1990) Development of a class of stable predictive variables: the case of bankruptcy prediction. J. Bus. Finan. \& Accoun. 17(1), 31-51.

22. Platt, HD and Platt MB (1991) A note on the use of industry-relative ratios in bankruptcy prediction. J. Banking \& Finan. 15(6), 1183-1194.

23- Premachandra IM, Bhabra GS and Sueyoshi T (2007) DEA as a tool for bankruptcy assessment: A comparative study with logistic regression technique. Eur. J. Operational Res. 193, 412-424.

24- Rose PS and Giroux GA (1984) Predicting corporate bankruptcy: An analytical and empirical evaluation. Rev. Bus. \& Econ. Res. 19(2), 1-12.

25• Rujoub M, Cook D and Hay L (1995) Using cash flow ratios to predict business failures. J. Managerial. 7(1), 75-90.

26- Shirata CY (1998) Financial ratios as predictor of bankruptcy in Japan: An Empirical Res., Tsukuba College of Technol., Japan.

27- Sorayaei A, Salimi MR and Divkolaii MS (2012) Probing efficiency scale of fuzzy neural network on forecasting stock exchange of the automobile industries. Indian J. Sci. \& Technol. 5(4), 2590-2592.

28- Springate Gord LV (1978) Predicting the possibility of failure in a Canadian firm. Unpublished MBA Res. Project. Simon Fraser Univ., January.

29- Sufian F, Zulkhibri M and Majid A (2007) Singapore banking efficiency and its relation to stock returns: A DEA window analysis approach. Intl. J. Business Study. 15(1), 83-106.

30- Sung T, Chang N and Lee G (1999) Dynamics of modeling in data mining: Interpretive approach to bankruptcy prediction. $J$. Manage. Info. Sys. 16(1), 63-85.

31- Xu X and Wang Y (2007) Financial failure prediction using efficiency as a predictor. Expert Sys. Appl. 36, 388-393.

32 Yang Z, Platt M and Platt H (1999) Probabilistic neural networks in bankruptcy prediction. J. Business Res. 44, 67-74.

33 Zavgren C (1985) Assessing the vulnerability to failure of American industrial firms: A logistic analysis. J. Bus. Finan. \& Accoun. 12(1), 19-45.

34- Zmijewski M (1984) Essays on corporate bankruptcy. Ph.D. dissertation, State Univ. NY-Bu 